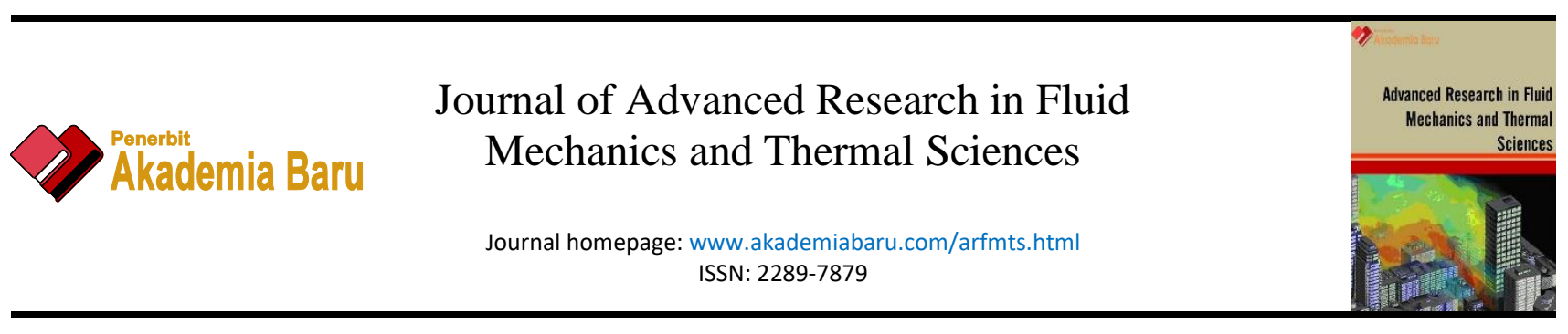

\title{
Feasibility of Cooling a Photovoltaic Fresnel System by Water Spraying
}

\author{
R. Shenouda ${ }^{1,},{ }^{*}$, M.S. Abd-Elhady ${ }^{1,2}$, H. A. Kandil ${ }^{1}$ \\ Department of Mechatronics, Faculty of Engineering and Materials Science, German university in Cairo, Cairo, Egypt \\ Department of Mechanical Engineering, Faculty of Engineering, Beni-Suef University, Beni-Suef, Egypt
}

ARTICLE INFO ABSTRACT

\section{Article history:}

Received 10 January 2020

Received in revised form 15 April 2020

Accepted 28 April 2020

Available online 31 July 2020

\section{Keywords:}

Fresnel system; Photovoltaic;

Concentration ratio; water cooling

\begin{abstract}
The Fresnel system can achieve high electrical energy yield compared to the traditional photovoltaic (PV) panel techniques due to the concentration of solar energy. However, this huge energy might cause overheating of the PV panel. The objective of this research is to mathematically model a linear Fresnel system that is cooled by either spraying the PV panel by tap water or chilled water, in order to determine the maximum possible concentration ratio, which is called the critical concentration ratio. Then, the model is further used to study the effect of cooling on the PV panel in real life operating conditions in two cities; the first one is a hot city which is Cairo, Egypt, and the other one is a cold city which is Stuttgart, Germany. The objective is to find out the Critical concentration ratio $(\mathrm{Cr})$ at which the maximum energy output from the system can occur as a function of the operating conditions. The results of this study show that cooling of the PV panels using chilled water system is not feasible. Therefore, in order to improve the feasibility, a low energy cooling system should be adopted. Such system may include spraying tap water on the PV panels, recollecting the water and cooling it naturally underground and finally spraying it again on the panels. The maximum output energy has increased by approximately $75 \%$, compared to the nocooling case, due to water spraying, which indicates the feasibility of water spraying in Fresnel systems.
\end{abstract}

Copyright @ 2020 PENERBIT AKADEMIA BARU - All rights reserved

\section{Introduction}

\subsection{Overheating Effect on the Efficiency of PV Panels}

One of the main obstacles that face the operation of the Fresnel system is overheating due to excessive solar radiation and high ambient temperatures which affect the panel's efficiency, output energy [1-4] and can even burn the PV panel [5-6]. One of the important parameters that affect the output of the Fresnel system is the concentration ratio. The concentration ratio is defined as the ratio between the actual solar irradiance on the PV panel at a certain instant, and the solar irradiance at

\footnotetext{
* Corresponding author.

E-mail address: ramy.shawkey@guc.edu.eg
}

https://doi.org/10.37934/arfmts.73.2.5672 
that instant [7-9]. Therefore, the output power increases in direct proportion to the concentration ratio. As the number of mirrors increases, the concentration ratio increases and the power input increases to a great extent causing overheating which reduces the output and may even burn the PV cells. However, there is a critical concentration ratio at which the maximum output power is produced. The critical concentration ratio depends on several physical parameters such as the ambient temperature, the solar irradiance and the area of the panel. Therefore, it is important to determine the critical concentration ratio and how it is affected in case of cooling the PV panel by water spraying.

\subsection{Cooling Techniques}

Many studies have been carried out on the cooling of PV systems to determine which cooling technique is more promising in providing the highest efficiency of the panel [10-11]. Hybrid Photovoltaic/Thermal (PV/T) solar system is one of the most popular methods for cooling the photovoltaic panels nowadays [12-14]. The hybrid system consists of a solar photovoltaic panel combined with a cooling system. The cooling agent, water or air, is circulated around the PV panels for cooling the solar cells, such that the warm water or air leaving the panels may be used for some domestic applications such as domestic heating [12]. Chaniotakis [12] designed a hybrid PV/T solar system where water and air were both investigated in the combined system as cooling agents. Chaniotakis compared two methods of cooling the photovoltaic panel. The first one is PV/T air heating collector and the second one is a water-cooled PV/T. The hybrid system consists of a PV panel and a heat exchanger consisting of pipes with fins. Natural ventilation of air passing through the gaps of the system absorbs the heat from the panel. It has been recorded that the overall efficiency of the system is higher than the efficiency of a PV module with no ventilation. The efficiency of the panel has a maximum value of $8.4 \%$ when the temperature was $67^{\circ} \mathrm{C}$ (minimum temperature value) and a minimum value of $7 \%$ when the temperature was $98^{\circ} \mathrm{C}$ (maximum temperature value). On the other hand, the water-cooled PV uses water as the coolant medium. It was operating in the range from $25^{\circ} \mathrm{C}$ to $30^{\circ} \mathrm{C}$. The PV/water based was operating at lower temperatures compared to air cooled systems. Consequently, the overall efficiency of the system was higher. The maximum efficiency was $12.5 \%$ at $27^{\circ} \mathrm{C}$. Therefore, the difference between these systems is about $4.1 \%$ in solar cell efficiency. Furthermore, the main advantage of the water-cooled system is that the heat absorbed can be used for various applications [15-16]. The PV/T water collector's thermal and electrical performance was investigated for two absorbers design [17] under different solar radiation levels, $300-1100 \mathrm{~W} / \mathrm{m}^{2}$, the first one is serpentine and the second one is a new serpin-direct design. The results showed the priority of serpin-direct collector design performance versus the serpentine design in terms of the thermal and electrical efficiency. The serpin-direct PV/T design achieved 53\% thermal and $14.3 \%$ electrical efficiency, respectively, at optimum conditions of $900 \mathrm{~W} / \mathrm{m}^{2}$ solar radiation and $0.06 \mathrm{~kg} / \mathrm{s}$ mass flow rate. It has been concluded by many researchers [18-20] that the water-cooled PV system proved to be more effective than the air-cooled PV. Akbarzadeh and Wadowski [21] presented a combined photovoltaic and thermal solar panels system. That system reduces the heat produced by the PV system and increased the output energy of the PV panels and thermal collector. They designed a hybrid PV/T solar system and found that the solar cells output power increases by almost $50 \%$ when the solar photovoltaic panel was cooled using water. They also found that the surface temperature of the solar cells reaches a maximum of $46^{\circ} \mathrm{C}$ when exposed to solar radiation for a period of $4 \mathrm{~h}$ using water as the cooling agent. As a good cooling media, water has been widely used for PV cooling in various forms. Kalogirou [22] studied a water-based PV/T system consisting of four monocrystalline PV panels in Cyprus and achieved an increase of average annual electrical efficiency from $2.8 \%$ to 
$7.7 \%$ with the payback periods of 4.6 years. Ghazali et al., [23] show that the photovoltaic system on a vertical façade of a high-rise building can be implemented with a careful design approach in Malaysia's climatic conditions. It was found that the payback period for the vertical photovoltaic system is about 12 years while the horizontal system is 6 years. Abdolzadeh and Ameri [24] used water spray to cool the PV panels and achieved an increase in the efficiency of cells by $3.26 \%$ to $12.5 \%$. Another cooling method was used by Musthafa [25] where the problem of overheating was partially avoided by fixing a water absorption sponge on the back side of the PV panel. The sponge maintains a wet condition by the circulation of drop by drop water through the sponge. The main objective of the work was to increase the panel's electrical efficiency by reducing the temperature of the solar cell [25]. Abdulgafar et al., [26] investigated the cooling of a PV panel via a water immersion technique. In their work, the performance and the electrical efficiency of polycrystalline silicon panel were improved using distillated water immersion technique. The objective was to study the behavior of a PV panel submerged in water and to optimize the efficiency of the panel by submerging it in distillated water at different depths. The panel is made of polycrystalline silicon. It was found that an evident increase of efficiency is found with increasing the water depth. Thermal drift has been reduced and the solar panel efficiency has increased by about $11 \%$ at a water depth of $6 \mathrm{~cm}$. From the above review, it can be concluded that many researches and efforts have been made to find an efficient cooling technology. The performance of the solar cells was analyzed using different technologies and various cooling fluids. Water and air cooling techniques are the most frequently used cooling techniques [27]. It was found that water cooling technique is the best cooling technique, as the solar cells' temperature decreases significantly, the electrical performance of the solar cells is enhanced in addition to the remarkable increase in the panel's efficiency when compared with any other cooling technique [28-29]. This research is focusing on modelling, analyzing and comparing two different cooling techniques on the Fresnel system. The former uses tap water in order to cool the panels while the latter uses chilled water as the coolant. The techniques are compared in order to show the effect of cooling on the solar panels' characteristics at different concentration ratios. The objective of this research is to develop a mathematical model, to estimate the net energy output from a Fresnel system as a function of the concentration ratio and different operating conditions including solar irradiance and ambient temperature. The model is applied in cases of constant and variable solar irradiances and ambient temperatures. The model is further developed to account for cooling the PV panels of the Fresnel system either by spraying tap water or chilled water. It is required to calculate the maximum net energy in both cases of cooling and compare them with the case of no cooling. The model is further used to find the critical concentration ratio $(\mathrm{Cr})$ at which the maximum energy output from the system can be obtained as a function of the operating conditions

\section{Materials and Methodology}

A mathematical model is first developed for a linear Fresnel system with no cooling and then the model was modified to take into account the cooling either by spraying tap water or chilled water over the glass surface of the PV panel. The electrical and physical characteristics of the PV panel used in the system are illustrated in Table 1. 
Table 1

Characteristics of the PV panel used in this research [30]

\begin{tabular}{ll}
\hline Model No. & BP 7185 \\
\hline Power rating & $185 \mathrm{~W}$ \\
Open circuit voltage & $44.8 \mathrm{~V}$ \\
Short circuit current & $55 \mathrm{~A}$ \\
Voltage at maximum power & $36.5 \mathrm{~V}$ \\
Current at maximum power & $5.10 \mathrm{~A}$ \\
Nominal voltage & $24 \mathrm{~V}$ \\
Panel efficiency & $14.7 \%$ \\
Fill factor & $75.1 \%$ \\
Power tolerance & $0.0-2.5 \%$ \\
Maximum system voltage $\mathrm{V}_{\text {max }}$ & $1000 \mathrm{~V}$ \\
Nominal operating cell temperature & $47^{\circ} \mathrm{C}$ \\
Air temperature, solar irradiance & $25^{\circ} \mathrm{C}, 1000 \mathrm{~W} / \mathrm{m}^{2}$ \\
Maximum series fuse rating & $15 \mathrm{~A}$ \\
Isc Temperature coefficient & $0.065 \% /{ }^{\circ} \mathrm{C}$ \\
Voc Temperature coefficient & $-0.36 \% /{ }^{\circ} \mathrm{C}$ \\
Pmp Temperature coefficient & $-0.5 \% /{ }^{\circ} \mathrm{C}$ \\
Cell type & $\mathrm{Monocrystalline} \mathrm{silicon}$ \\
Cell size (mm $\times$ mm) & $125 \times 125$ \\
Panel dimensions in mm & $1593 \times 790 \times 50$ \\
Weight & $15.4 \mathrm{~kg}$ \\
\hline
\end{tabular}

\subsection{The No Cooling Model}

The module temperature, $T_{m}$, at a certain solar irradiance, $E$, and ambient temperature, $T_{a m b}$, can be calculated using the model developed by Garcia and Balenzatgeui [31] as follows

$\mathrm{T}_{\mathrm{m}}=\mathrm{T}_{\mathrm{amb}}+(\mathrm{NOCT}-20) \times \frac{\mathrm{G}}{800} \times \mathrm{Cr}$

where $T_{a m b}$ is the ambient temperature, NOCT is the nominal operating cell temperature of the Photovoltaic (PV) module, $\mathrm{G}$ is the solar irradiance and $\mathrm{Cr}$ is the concentration ratio. The $\mathrm{Cr}$ has been added to the model of Garcia and Balenzatgeui [31], in order to account for the actual solar irradiance over the PV panel because of using the Fresnel system. The NOCT is a constant value given by the manufacturer of the PV panels, and it is taken in this research as $47^{\circ} \mathrm{C}$. The solar irradiance is taken as an average value of $1000 \mathrm{~W} / \mathrm{m}^{2}$. The ambient temperature is measured as an average temperature of the whole day and it is taken as $25^{\circ} \mathrm{C}$. The power output from the PV panel $\mathrm{P}_{@ \mathrm{~T}_{\mathrm{m}}}$ at a certain module temperature can be calculated based on the following model, developed by Skoplaki and Palyvos [32], as follows

$\mathrm{P}_{\Theta \mathrm{T}_{\mathrm{m}}}=\eta_{\mathrm{ref}} \times \mathrm{G} \times \mathrm{A}\left(1-\beta_{\text {ref }}\left(\mathrm{T}_{\mathrm{m}}-25\right)\right) \times \mathrm{Cr}$

where $\eta_{\text {ref }}$ is the efficiency of the PV panel at the standard operating conditions, $A$ is the area of the panel and $\beta_{\text {ref }}$ is the power temperature coefficient. The concentration ratio $\mathrm{Cr}$ has been added to the model of Skoplaki and Palyvos [32], in order to account for the increase in solar irradiance over the PV panel due to using the Fresnel system, such that $\mathrm{G} \times \mathrm{Cr}$ represents the actual solar irradiance over the PV panel. The average output energy $E_{1}$ from the PV panel can be calculated by multiplying the actual power output from the PV panel by the daily average time of peak Sunshine $\Delta t$ as follows 


$$
\mathrm{E}_{1}=\eta_{\text {ref }} \times \mathrm{G} \times \mathrm{A} \times\left(1-\beta_{\text {ref }}\left(\mathrm{T}_{\mathrm{m}}-25\right)\right) \times \mathrm{Cr} \times \Delta \mathrm{t} .
$$

The daily average time of peak sunshine in Egypt is taken as 6 hours [33]. The output energy from a PV panel as a function of the concentration ration is plotted in Figure 1 based on Eq. (3), in case of a PV panel of an area of $1.26 \mathrm{~m}^{2}$, reference efficiency of $10 \%$ and the temperature coefficient of the $\mathrm{PV}$ panels is $-0.5 \% /{ }^{\circ} \mathrm{C}$, which indicates that every $1^{\circ} \mathrm{C}$ of temperature rise corresponds to a drop in the efficiency by $0.5 \%$.

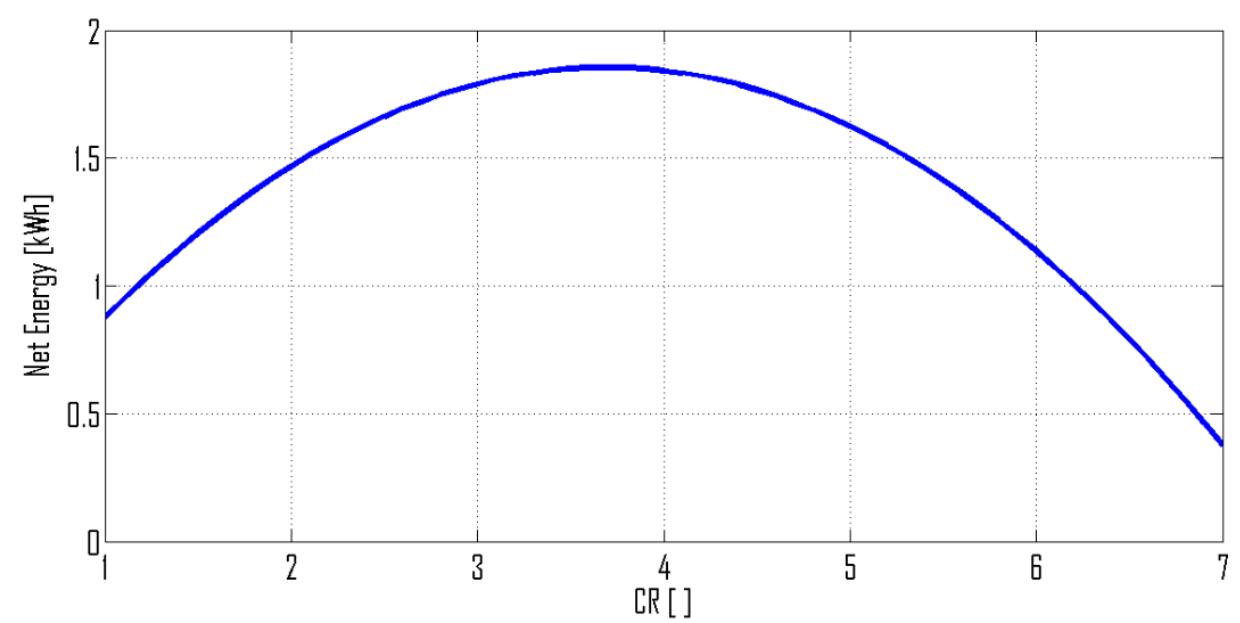

Fig. 1. Output energy from the Fresnel system versus concentration ratio, $\mathrm{Cr}$, at a constant solar irradiance, $\mathrm{G}$, of $1000 \mathrm{~W} / \mathrm{m}^{2}$ and ambient temperature of $25^{\circ} \mathrm{C}$

It can be seen from Figure 1 that the critical concentration ratio appears to be at a value of $\mathrm{Cr}=$ 4. As the concentration ratio increases beyond the critical value, the input energy increases, but the module temperature increases resulting in decreasing the overall panel's efficiency and output energy.

\subsection{Modeling of Cooling the PV Panel by Spraying Tap Water}

The cooling system of the PV panel by water spraying consists mainly of (1) a water pump, (2) a dust filter, (3) water nozzles, (4) a drain, (5) a water tank and connecting pipes, as shown in Figure 2. The cooling system is adopted from Moharram et al., [30]. The water pump sucks the water from the middle of the water tank via a suction pipe to avoid sucking any dust. The suction pipe contains a non-return valve and a strainer to avoid sucking large particles that could damage the pump. The water passes through the filter, and then, it is sprayed over the PV modules for cooling, as shown in Figure 2(a). Afterward, the water used for cooling is collected and returned back to the water tank. The water tank is buried under ground to avoid heating by solar radiation and also to cool the water inside the tank by the surrounding soil. The hot water coming from the PV panel is cooled due to mixing with the large amount of cold water inside the tank. When the water is sprayed on the PV panel, the panel is cooled where its temperature decreases from $T_{m}$ to $T_{a m b}$ during a certain time and then it is heated again by the sunshine. The temperature of the panel increases because of the solar irradiance to reach a high temperature, $T_{m}$, at which the cooling system starts. The cooling process continues until the temperature drops from $T_{m}$ to the ambient temperature, $T_{a m b}$, at which the cooling stops. The cycle of heating and cooling is repeated several times within the sunshine time. The number of cycles required for cooling the panel during its operation is required to calculate the 
pumping energy. Therefore, the time of operation of the PV panel, i.e. 6 hours, is divided by the total time required for heating and cooling the panel. The time taken for heating the panel due to the solar irradiance, $t_{1}$, is calculated using the following equation:

$\mathrm{t}_{1}=\frac{\mathrm{m}_{\mathrm{g}} \times \mathrm{c}_{\mathrm{g}} \times \Delta \mathrm{T}}{\mathrm{G} \times \mathrm{A} \times \mathrm{Cr}}$

where $\mathrm{m}_{\mathrm{g}}$ is the mass of the glass, $\mathrm{c}_{\mathrm{g}}$ is the specific heat of the glass, $\Delta \mathrm{T}$ is the temperature difference, which equals to $T_{m}-T_{a m b}$. Since the solar cells are manufactured from silicon which is almost glass and they are covered by glass, therefore, the glass physical properties are used as the physical properties of the PV panels. The mass of glass $\mathrm{m}_{\mathrm{g}}$ is calculated using the following equation:

$\mathrm{m}_{\mathrm{g}}=\rho \times \mathrm{A} \times \mathrm{x}_{\mathrm{g}}$

where $\rho$ is the density of the tempered glass and $\mathrm{X}_{\mathrm{g}}$ is the thickness of the glass covering the PV panel. The mass of the glass $\mathrm{m}_{\mathrm{g}}$ is $15.4 \mathrm{~kg}$, and the specific heat $\mathrm{c}_{\mathrm{g}}$ is taken as $0.84 \mathrm{~kJ} / \mathrm{kg}^{\circ} \mathrm{C}$. The incident solar rays fall on the mirrors, which have different angles of inclination $\alpha_{i}$ with the horizontal, where $i$ is $1,2,3$,...etc. Each mirror is located at a certain distance $X_{i}$ from the PV panel. The angle of inclination of each mirror $\alpha_{i}$ is related to its distance $X_{i}$ from the PV panel according to the following equation:

$2 \alpha_{i}=\tan ^{-1} \frac{X_{i}}{H}$

where $\mathrm{H}$ is the distance between the reflector and the PV panel. The solar rays are reflected by the mirrors at the same point on a reflector, as shown in Figure 2(b), and then it is reflected once again on the PV panel.

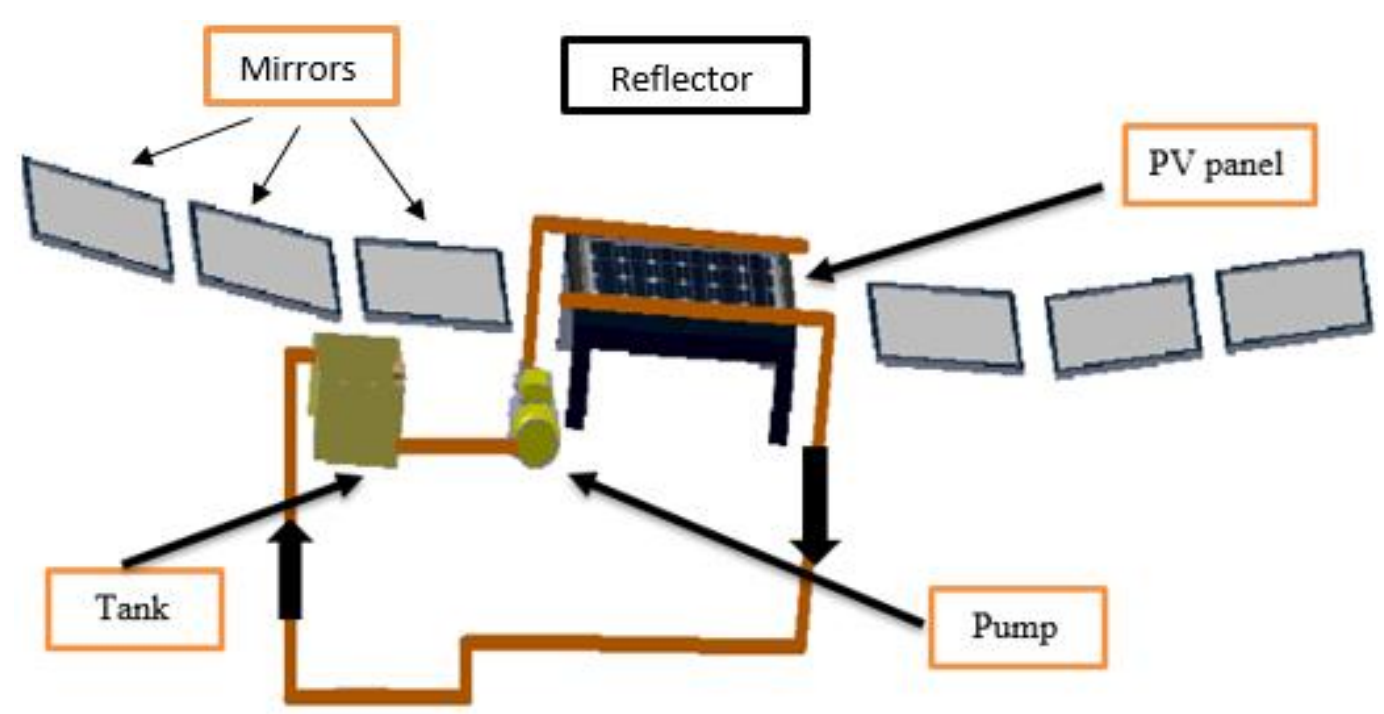

(a) 


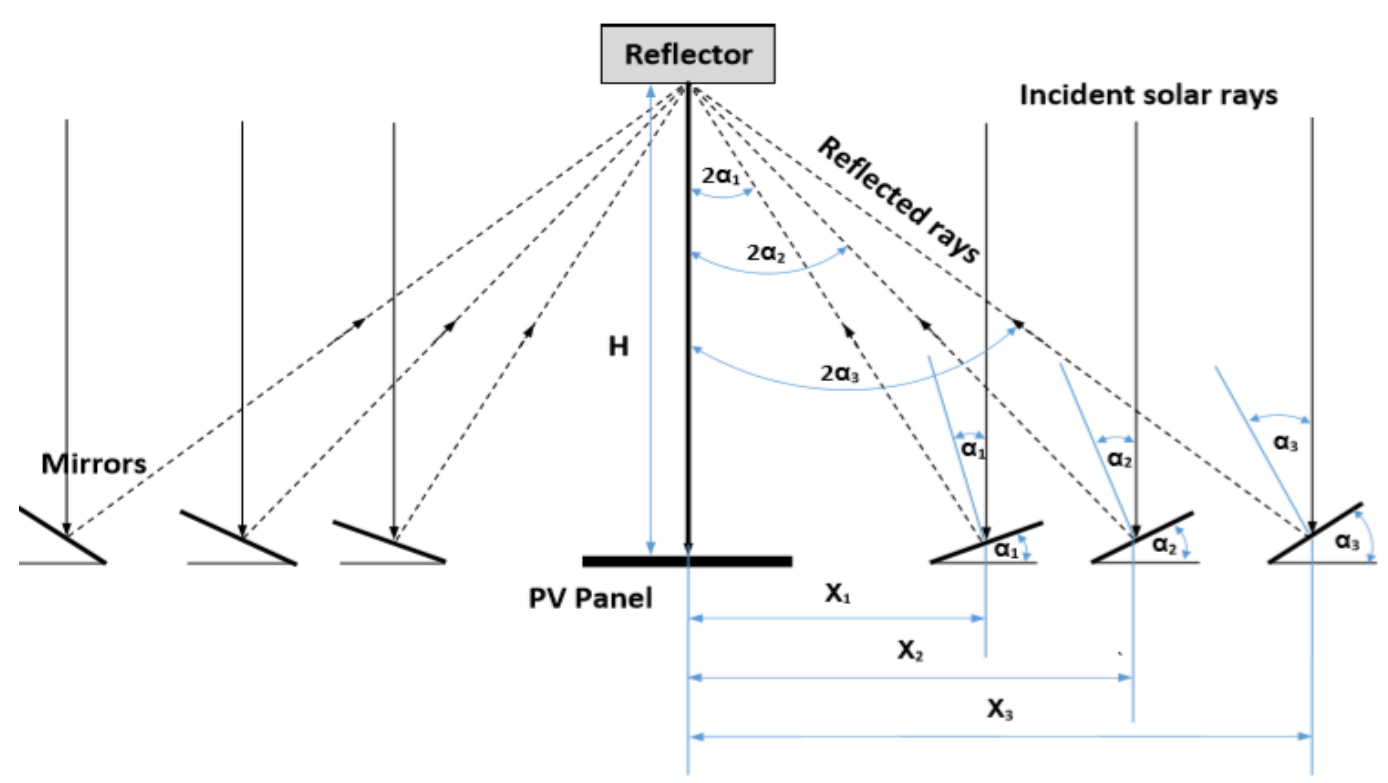

(b)

Fig. 2. (a) A sketch of the cooling system implemented by spraying tap water over the PV panel and (b) a schematic diagram of the sunrays relative to the reflecting mirror and the PV panel

The average output power of the panel is calculated using the following equation:

$\mathrm{P}_{\mathrm{avg.}}=\frac{\left(\mathrm{P}_{@ \mathrm{~T}_{\mathrm{m}}}+\mathrm{P}_{@ \mathrm{~T}_{\mathrm{amb}} .}\right)}{2}$.

The average output energy, $E_{1}$, of the PV panel is calculated by multiplying the average output power by 6 which is the average daily sunshine hours in Egypt. The rate of cooling of the PV cells is an important factor that highly affects their performance. Therefore, by determining the cooling rate of the PV cells, the cooling period can be specified. The cooling time, $t_{2}$, is determined based on an energy balance, such that the heat energy gained by the cooling water, $Q_{w}$, is equal to the heat energy dissipated from the PV panel, Qg. The heat energy dissipated from the PV panel is equal to:

$\mathrm{Q}_{\mathrm{g}}=\mathrm{m}_{\mathrm{g}} \times \mathrm{c}_{\mathrm{g}} \times \Delta \mathrm{T}$,

while the heat energy gained by the cooling water is equal to:

$\mathrm{Q}_{\mathrm{w}}=\dot{\mathrm{m}}_{\mathrm{w}} \times \mathrm{c}_{\mathrm{w}} \times \Delta \mathrm{T}_{\mathrm{w}} \times \mathrm{t}_{2}$

where $\dot{\mathrm{m}}_{\mathrm{w}}$ is the mass flow rate of the cooling water, $\mathrm{C}_{\mathrm{w}}$ is the specific heat of water, $\Delta \mathrm{T}_{\mathrm{w}}$ is the water temperature rise due to the heat energy gained from the PV panel, and $t_{2}$ is the time required for cooling the PV panel from $T_{m}$ to $T_{a m b}$ and it can be calculated by equating Eq. (8) and Eq. (9) as follows

$\mathrm{t}_{2}=\frac{\mathrm{m}_{\mathrm{g}} \times \mathrm{c}_{\mathrm{g}} \times \Delta \mathrm{T}}{\dot{\mathrm{m}}_{\mathrm{w}} \times \mathrm{c}_{\mathrm{w}} \times \Delta \mathrm{T}_{\mathrm{w}}}$ 
The number of cycles, $\mathrm{N}$, needed for cooling the PV panel during the day is calculated using the following equation:

$\mathrm{N}=\frac{\mathrm{t}^{\prime}}{\mathrm{t}}$

where $t^{\prime}$ is sunshine time, and $t$ is the total time required for heating and cooling the PV panel and it is equal to $t_{1+} t_{2}$. The water pumping energy, $E_{2}$, needed by the cooling system, i.e. water pump, per day is calculated based on the following equation:

$E_{2}=P_{\text {pump }} \times t_{2} \times N$

where $P_{\text {pump }}$ is the rated power of the pump. The net energy generated from the Fresnel system is then calculated by subtracting $E_{2}$ from $E_{1}$. The net energy generated from the proposed Fresnel system after cooling by spraying tap water is calculated and the results are presented in Figure 3 . The net energy is calculated based on a water mass flow rate, $m_{\text {water, }}$ of $0.48 \mathrm{~kg} / \mathrm{s}$, specific heat of water $\mathrm{c}_{\mathrm{w}}$ of $4.18 \mathrm{~kJ} / \mathrm{kg}^{\circ} \mathrm{C}$, the specific heat of glass, $\mathrm{c}_{\mathrm{g}}$, of $0.84 \mathrm{~kJ} / \mathrm{kg}^{\circ} \mathrm{C}$, water temperature rise, $\Delta \mathrm{T}_{\mathrm{w}}$, of $5^{\circ} \mathrm{C}$ and a water pump of $120 \mathrm{~W}$ power. It is noted from Figure 3 that the net energy after cooling the PV panel reaches a maximum value at $\mathrm{Cr}=7$.

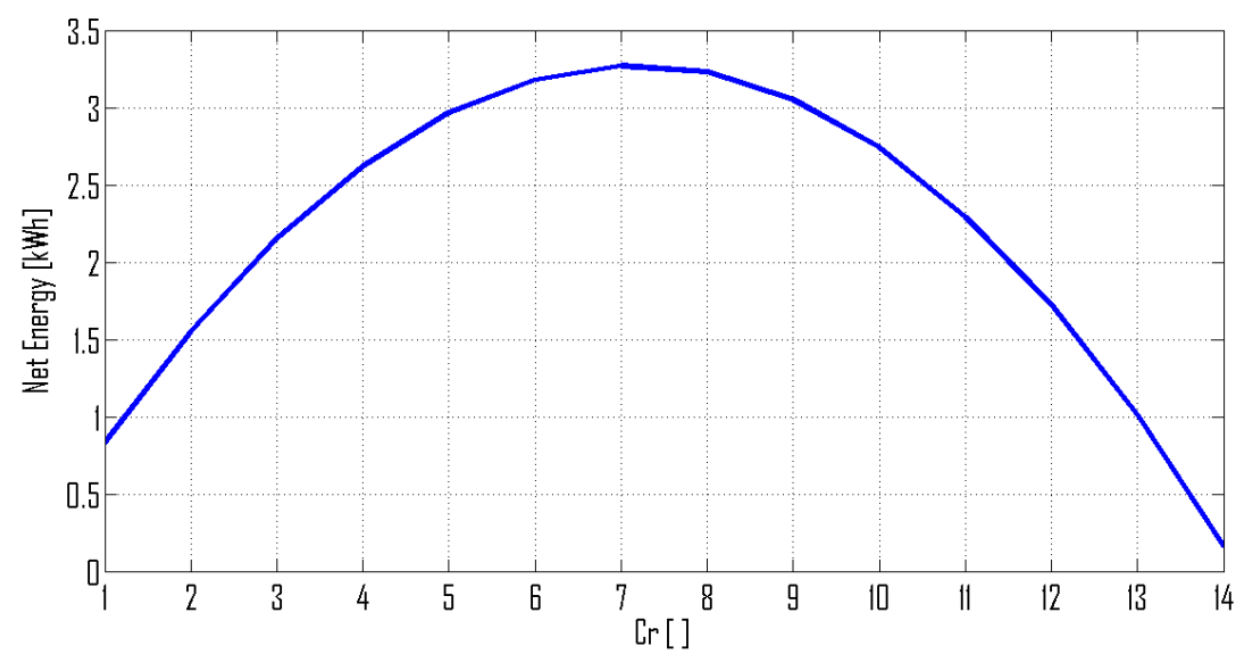

Fig. 3. Net output energy from the Fresnel system, which is cooled by spraying tap water over the surface of the PV panel versus concentration ratio, $\mathrm{Cr}$

\subsection{Modeling of Cooling the PV Panel by Spraying Chilled Water}

The same system used for cooling the PV panel by spraying tap water is used in this case except that chilled water is used instead of tap water. The water pump sucks the water from the water tank via a suction pipe to avoid sucking any dust. The suction pipe is connected to a refrigeration unit, as shown in Figure 4. The chilled water passes through the water filter, and then it is sprayed over the PV modules for cooling using nozzles. The panel is cooled from $T_{m}$ to $T_{a m b}$ during a certain time. This process is repeated several times during the daily sunshine time. The number of cycles, $\mathrm{N}$, required for cooling the panel during the time of operation of the PV panel is determined by dividing the time of operation per day by the total time required for heating, $t_{1}$, and cooling the panel, $t_{2}$ during one cycle of operation. The cooling energy, $E_{3}$, required to cool down the PV panel from $T_{m}$ to $T_{a m b}$ is 
calculated by multiplying the total heat dissipated from the panel, $Q_{g}$, and the pumping power by the number of cooling cycles per day, $\mathrm{N}$, as follows

$$
\mathrm{E}_{3}=\left(\frac{\mathrm{Q}_{\mathrm{g}}}{\text { C.O.P. }}+\left(\mathrm{P}_{\text {pump }} \times \mathrm{t}_{2}\right)\right) \times \mathrm{N}
$$

where C.O.P. is the coefficient of performance of the refrigerating unit and it is taken as 3 , which is an average value for refrigerating machines. The net energy generated from the panel is calculated by subtracting $E_{3}$ from $E_{1}$, where $E_{1}$ is the average output energy from the PV panel. The results are presented in Figure 5. It is noted from Figure 5 that the net energy output from the PV panel, in case of cooling by spraying chilled water, has decreased to a huge extent and it becomes a negative value with no critical concentration ratio. The decrease in the net energy output from the panel is due to the refrigeration energy required for cooling the chilled water. Comparing the performance of the PV panel without cooling and those with cooling by spraying tap water and chilled water, It can be seen from Figure 1 and Figure 3 that the critical concentration ratio changes from 4, in case of no cooling, to 7, in case of cooling by spraying tap water over the surface of the panel. Also, the net energy output from the Fresnel system has increased from $1.85 \mathrm{kWh}$, in case of no cooling, to $3.33 \mathrm{kWh}$, in case of cooling by spraying tap water, which corresponds to an increase of $79 \%$ in the total energy output.

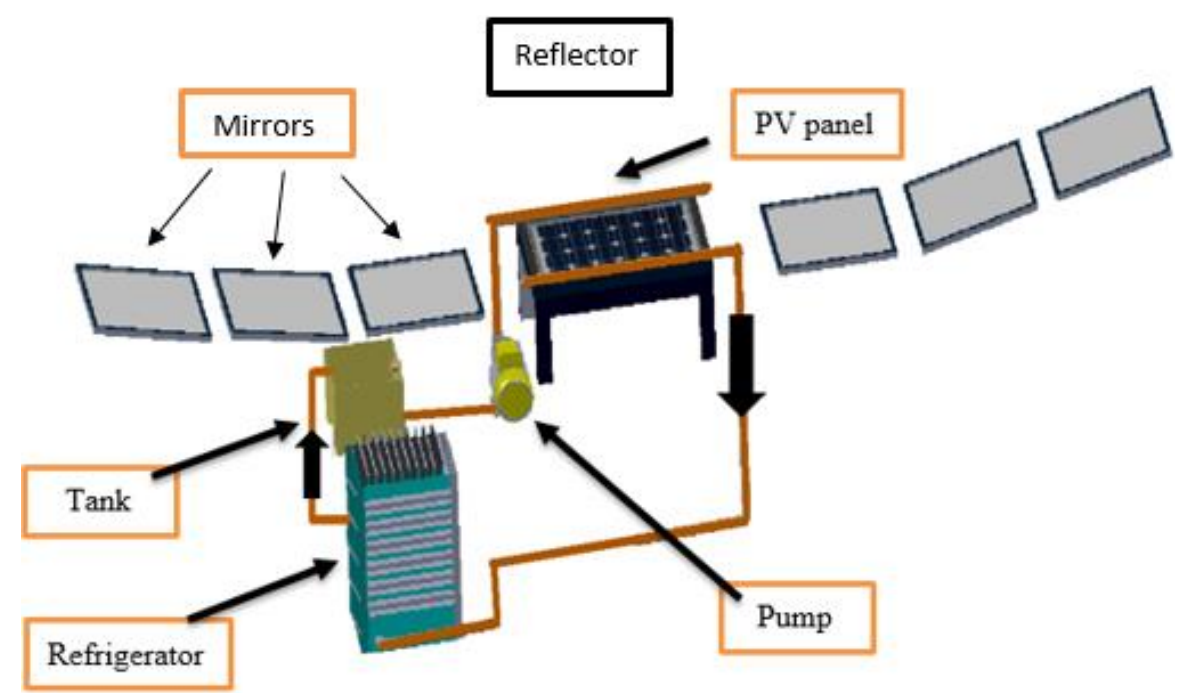

Fig. 4. Cooling of the PV panel of the Fresnel system by spraying chilled water over the panel 


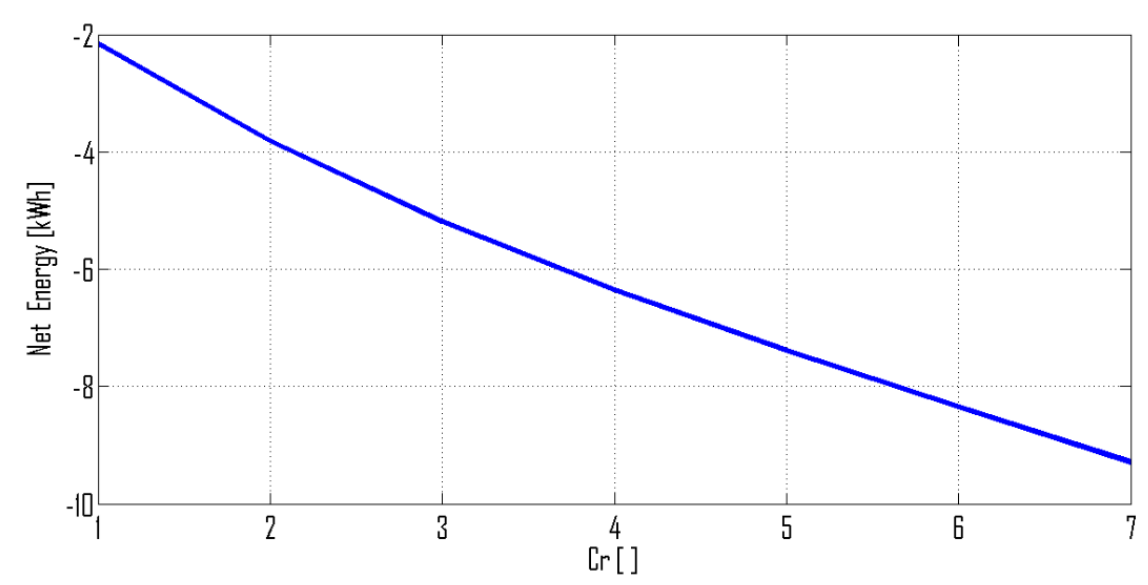

Fig. 5. Net Energy Output from the Fresnel system, which is cooled by spraying chilled water over the surface of the PV panel, versus concentration ratio, $\mathrm{Cr}$

\section{Results and Discussions}

The mathematical model developed in this study was used to study the effect of cooling by spraying tap water or chilled water on a Fresnel system as a function of the concentration ratio at a constant solar irradiance and ambient temperature. The model is then used to study the effect of cooling on the PV panel in operating conditions in two cities, the first one is a hot city, i.e. Cairo in Egypt, and the other one is a cold city i.e. Stuttgart in Germany, to find out the critical concentration ratio $(\mathrm{Cr})$ at which the maximum energy output from the system occurs as a function of the operating conditions.

\subsection{The Critical Cr of a Fresnel System that is Cooled by Spraying Tap Water and Installed in Stuttgart}

First, the effect of no cooling and cooling by spraying tap water on the Fresnel system performance in Stuttgart at variable operating conditions, such as solar irradiance and ambient temperature, is studied during the selected four months of the year. These months are January, April, July and October, which represent the four seasons of the year. The ambient temperature, $T_{a m b}$, is determined based on the average temperature of the midday of each month throughout the whole year. The solar irradiance, $G$, is taken each hour on the 15th day of each month. The output energy from the panel is calculated at different concentration ratios for different months of the year.

The results are presented in Figure 6 for the case of no cooing, and in Figure 7 for the case of cooling by spraying tap water over the surface of the panel. The critical concentration ratio increased from 21 for the case of no cooling to 41 for the case of cooling by spraying tap water, in the cold month of January, as presented in Table 2, while, the maximum output energy from the PV panel without cooling was $11 \mathrm{kWh}$ and that with cooling became $19 \mathrm{kWh}$, as indicated in Table 3 . This means that the net energy increased by $8.5 \mathrm{kWh}$, i.e.77\%. However, in July, which is a hot month, the critical concentration ratio increased from 6 , in case of no cooling, to 11 , in case of cooling by spraying tap water. The maximum output energy, from the PV panel before cooling, was $40.26 \mathrm{kWh}$ and it became $70.8 \mathrm{kWh}$ after cooling, which means that the net energy increased by $30.54 \mathrm{kWh}$, i.e. $75 \%$. 


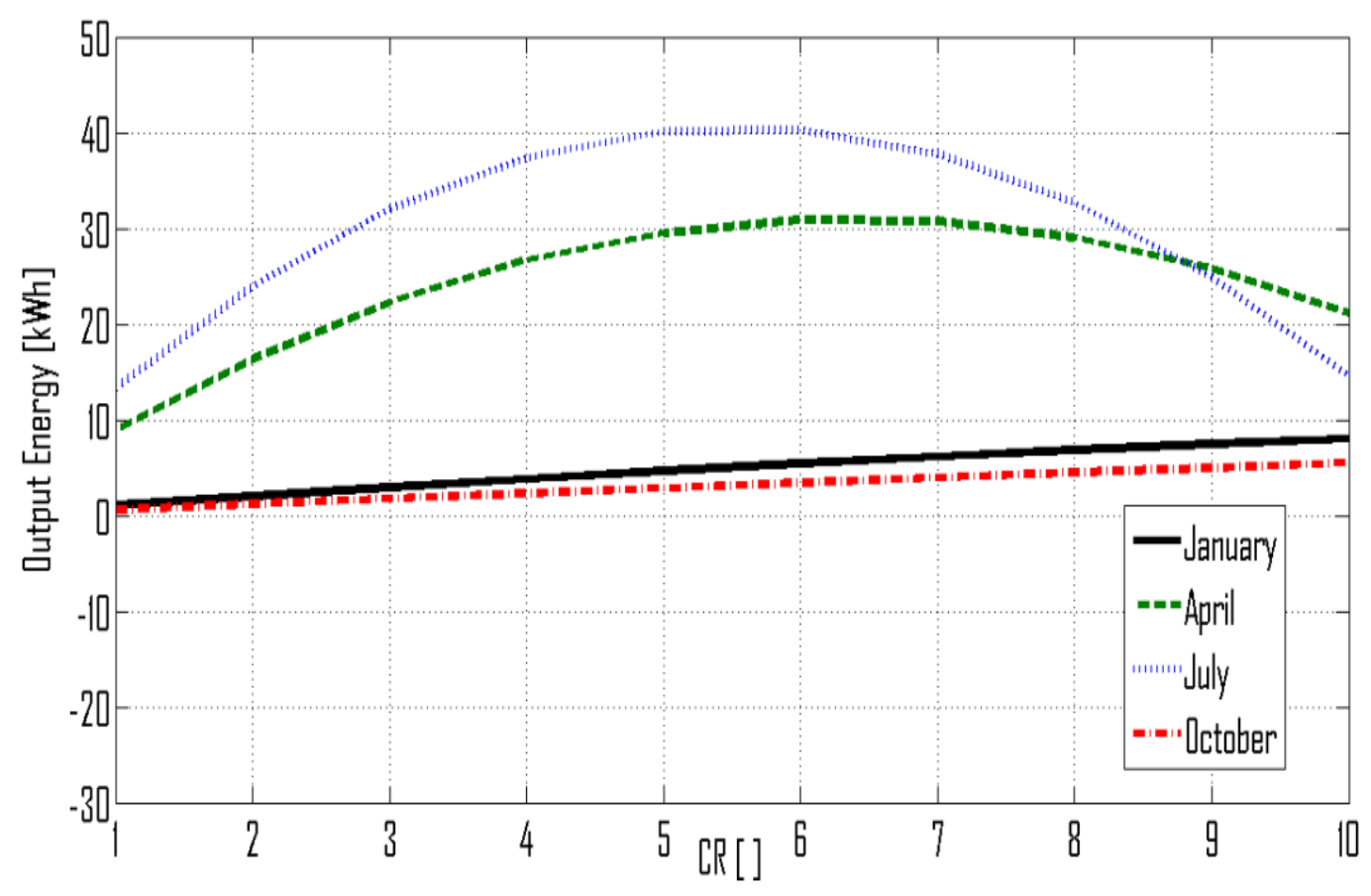

Fig. 6. Output energy from the Fresnel system versus $\mathrm{Cr}$ in the months of January, April, July and October in Stuttgart, Germany

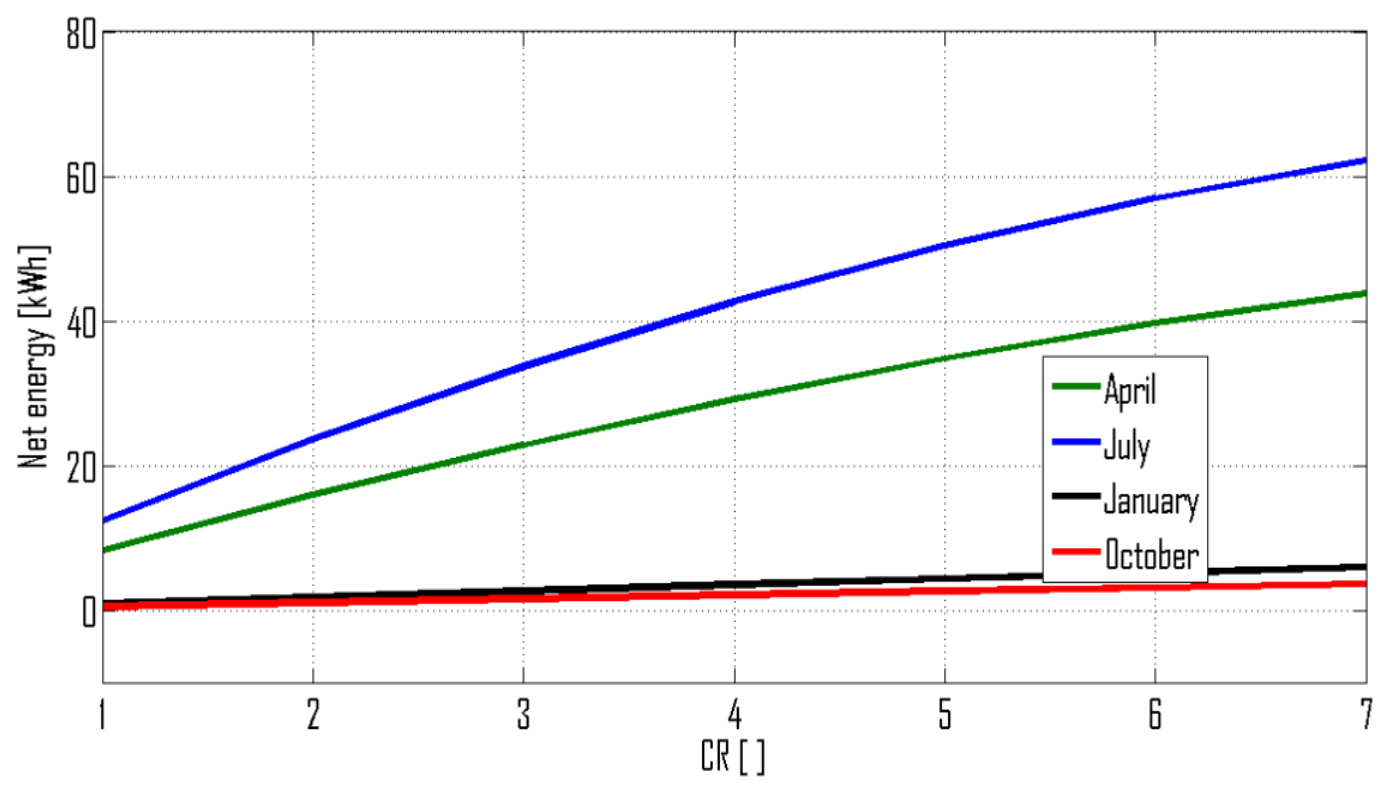

Fig. 7. Output energy from the Fresnel system versus $\mathrm{Cr}$ in the months of January, April, July and October in Stuttgart, Germany. The Fresnel system is cooled by spraying tap water over the surface of the PV panel

The results of the critical concentration ratio and the net output energy, as function of the month of the year, in case of no cooling and cooling by spraying tap water in Stuttgart, Germany, are presented in Table 2 and Table 3, respectively. It can be seen from Table 3 that as the critical concentration ratio increases, the maximum output energy from the PV panel decreases i.e. the critical concentration ratios in the hot months are very low compared to those in the cold months. For example, the maximum output energy from the PV panel in October (a cold month) at a concentration ratio $=59$ is $11 \mathrm{kWh}$, while in July (a hot month), the maximum output energy at a concentration ratio $=6$ is $41 \mathrm{kWh}$ and this is due to the high temperature of the surroundings during 
the summer, $T_{a m b}$, and the high solar irradiance, $G$. This means that the PV panel reaches its maximum output energy at a small concentration ratio. However, in January, the solar irradiance and the ambient temperature are very low. Therefore, the number of mirrors reflecting the sunrays, i.e. concentration ratio must be large in order to be able to extract the maximum output energy from the PV panel. This is clearly shown in the values of the maximum output energy extracted from the PV panel in both October and July.

\section{Table 2}

Critical concentration ratio without and with cooling by spraying tap water as a function of the month of the year in Stuttgart, Germany

\begin{tabular}{lll}
\hline Month & Critical ratio (No cooling) & Critical ratio (cooling by tap water) \\
\hline January & 21 & 41 \\
April & 6 & 12 \\
July & 6 & 11 \\
October & 59 & 126 \\
\hline
\end{tabular}

Table 3

Maximum net energy without and with cooling by spraying tap water as a function of the month of the year in Stuttgart, Germany

\begin{tabular}{lll}
\hline Month & $\begin{array}{l}\text { Max net energy without } \\
\text { cooling }(\mathrm{kWh})\end{array}$ & $\begin{array}{l}\text { Max net energy with cooling } \\
(\mathrm{kWh})\end{array}$ \\
\hline January & 11 & 19 \\
April & 31 & 54 \\
July & 41 & 71 \\
October & 18 & 31 \\
\hline
\end{tabular}

3.2 The Critical Cr of a Fresnel System that is Cooled by Spraying Chilled Water and Installed in Stuttgart

The net energy output from the PV panel in case of cooling using chilled water is shown in Figure 8. It can be noted from Figure 8 that the energy output decrease as the concentration ratio increases, moreover, the net energy obtained is always negative. For example, the net energy obtained from the PV panel in July at $\mathrm{Cr}=7$ is $-156 \mathrm{kWh}$ which is the maximum net energy obtained compared to those of the other months. This is due to the high temperature of the PV panel, $T_{m}$, at different concentration ratios during July, which requires dissipating a huge amount of heat from the PV panel in order to cool it from $T_{m}$ to $T_{a m b}$. However, the net energy obtained from the PV panel in October at $\mathrm{Cr}=7$ is $-9.6 \mathrm{kWh}$ which is the minimum net energy obtained compared to the those of the other months. This is due to the low temperature of the PV panel, $\mathrm{T}_{\mathrm{m}}$, at different concentration ratios during October, which requires dissipating a small amount of heat from the PV panel in order to cool it from $T_{m}$ to $T_{a m b}$. Despite this, it is clear that the cooling energy required in case of using chilled water is always greater than the energy extracted from the PV panel with no cooling at the operating conditions in Stuttgart which indicates the absence of the inflection point, i.e. the critical concentration ratio. It is concluded that using chilled water in cooling is ineffective in comparison to the tap water spraying cooling technique, from the energy point of view, in addition to the absence of the inflection point. 


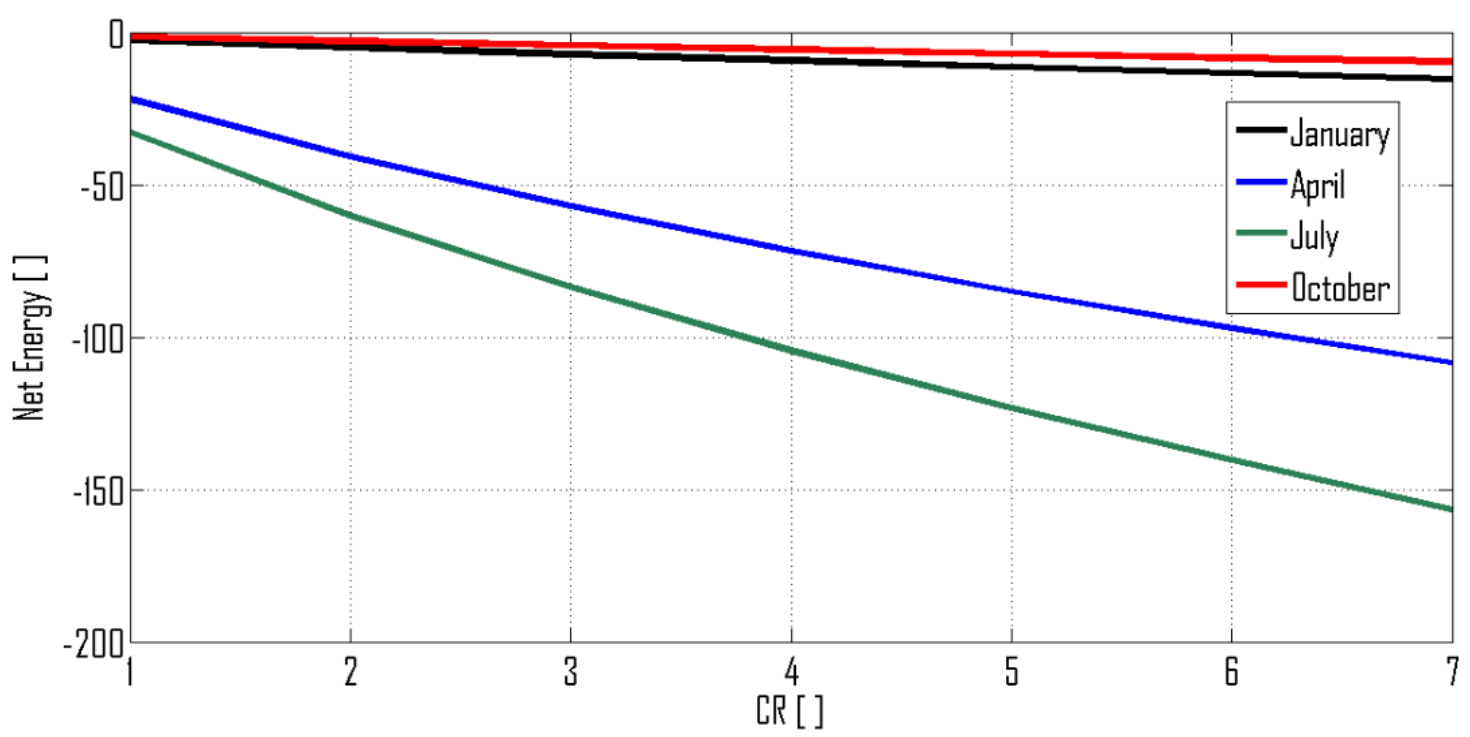

Fig. 8. Output energy from the Fresnel system versus $\mathrm{Cr}$ in the months of January, April, July and October in Stuttgart, Germany, the Fresnel system is cooled by spraying chilled water over the surface of the PV panel

\subsection{The Critical Cr of a Fresnel System that is Cooled by Spraying Tap Water and Installed in Egypt}

The same analysis done in case of Stuttgart will be performed to Egypt. The effect of cooling on the PV panel performance in Egypt will be applied during July, which is a hot month and December, which is a cold month. The output energy is calculated, at different concentration ratios, till the inflection point appears, which determines the critical concentration ratio at which the output energy reaches its maximum. After calculating the average output energy from the PV panel, $E_{1}$, and the pumping energy, $E_{2}$, the net energy of the PV panel is calculated by subtracting $E_{2}$ from $E_{1}$ and the results are shown in Figure 9 and Figure 10. It is found that the critical concentration ratio in July increased from $\mathrm{Cr}=5$, at no cooling, to $\mathrm{Cr}=9$, with cooling with water spraying, as shown in Figure 9. While, in December it increased from $\mathrm{Cr}=12$ to $\mathrm{Cr}=23$, as shown in Figure 10. The output energy obtained from the PV panel in July without cooling was $59 \mathrm{kWh}$. However, with cooling the net energy became $105 \mathrm{kWh}$, which means that the energy increased by $46 \mathrm{kWh}$, about $78 \%$, which clearly shows the huge effect of cooling by tap water spraying on the PV panel performance. The output energy from the panel in December, without cooling, was $28 \mathrm{kWh}$, however, with cooling, the net energy became $46 \mathrm{kWh}$. This means that the energy increased by $18 \mathrm{kWh}$, about $64 \%$, which also shows the large effect of cooling by tap water spraying on the output energy of the PV panel.

\subsection{The Critical Cr of a Fresnel System that is Cooled by Spraying Chilled Water and Installed in Egypt}

The same analysis done in case of Stuttgart will be performed in the case of Egypt, for the case of cooling using chilled water. The effect of cooling on the PV panel performance using chilled water will be applied during July, which is a hot month, and December, which is a cold month. The net energy is calculated by subtracting the cooling energy, $E_{3}$, from the average output energy, $E_{1}$, and the results are shown in Figure 9 and Figure 10. It is found that the critical concentration ratio in July was 5 at no cooling. However, the inflection point disappeared after cooling with chilled water. In December, the critical concentration ratio was 12 at no cooling. However, the inflection point disappeared and the net energy decreased gradually in direct proportion with the concentration ratio. Therefore, there is no critical concentration ratio in case of cooling with chilled water, as shown 
in Figure 9 and Figure 10. The output energy from the PV panel in July, without cooling, at $\mathrm{Cr}=5$ was $59 \mathrm{kWh}$, as shown in Table 4. However, with cooling, the net energy at this concentration ratio became -199 kWh which means that the energy decreased to a large extent and became negative which clearly shows the huge effect of cooling by chilled water on decreasing the PV panel energy output. The maximum output energy from the PV panel in December, without cooling, is $28 \mathrm{kWh}$ at $\mathrm{Cr}=12$, as shown in Table 5. However, with cooling, the net energy at the same concentration ratio became $-87 \mathrm{kWh}$. It is clear from the results that using chilled water as a cooling technique is ineffective in comparison to the tap water spraying cooling technique from the energy point of view, i.e. the net energy is negative, in addition to the absence of the inflection point.

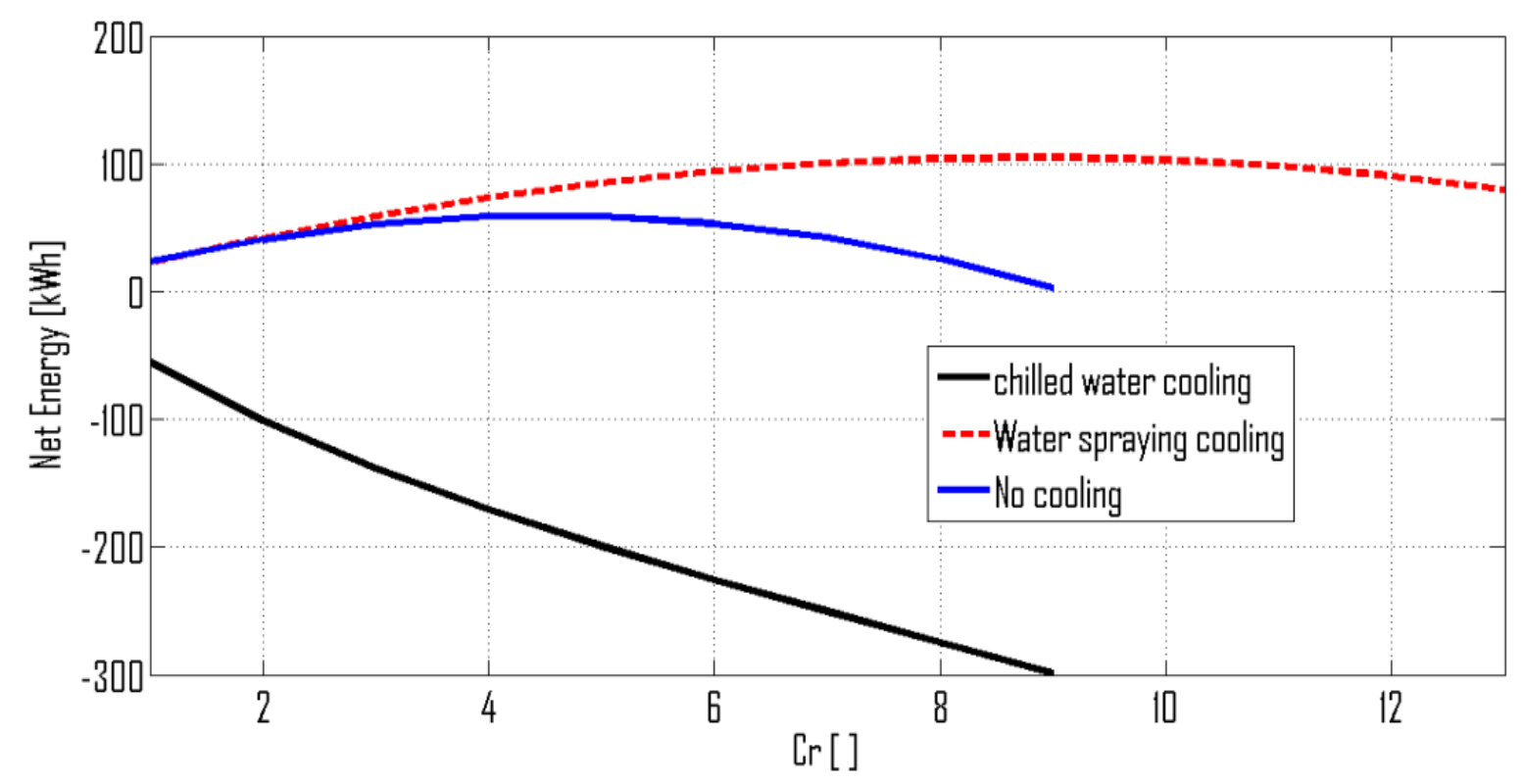

Fig. 9. Net energy versus $\mathrm{Cr}$ in July in Egypt

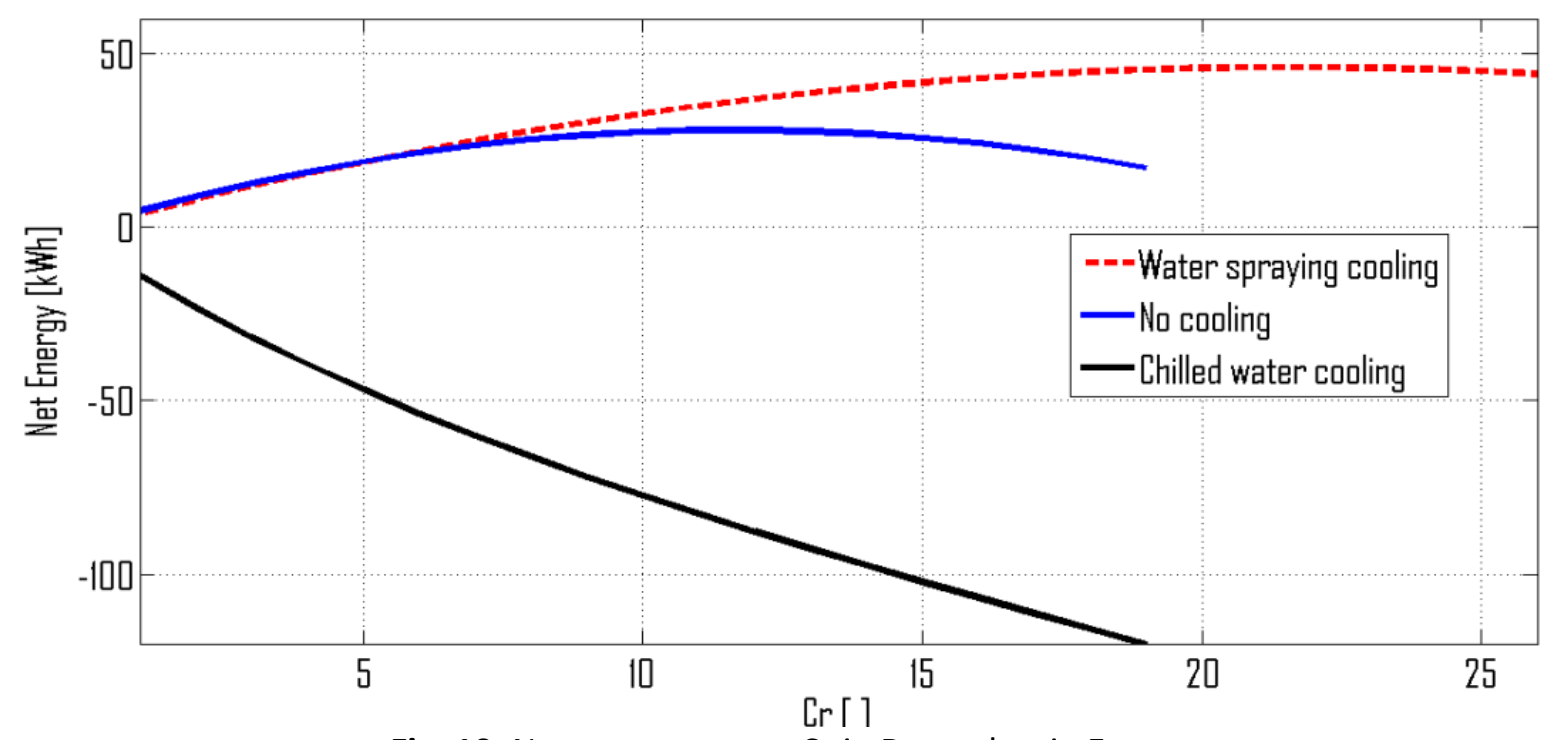

Fig. 10. Net energy versus $\mathrm{Cr}$ in December in Egypt 
Table 4

Maximum net energy without and with cooling in July in Egypt

\begin{tabular}{llll}
\hline Type of cooling & No cooling & water spraying & Chilled water \\
\hline Critical Cr. & $\mathrm{Cr}=5$ & $\mathrm{Cr}=9$ & No critical $\mathrm{Cr}$ \\
Max. net energy & $59 \mathrm{kWh}$ & $105 \mathrm{kWh}$ & -ve value \\
\hline
\end{tabular}

\section{Table 5}

Maximum energy without and with cooling in December in Egypt

\begin{tabular}{llll}
\hline Cooling Type & No cooling & Water spraying & Chilled water \\
\hline Critical $\mathrm{Cr}$ & $\mathrm{Cr}=12$ & $\mathrm{Cr}=22$ & No critical $\mathrm{Cr}$ \\
Max. net energy & $28 \mathrm{kWh}$ & $46 \mathrm{kWh}$ & -ve value \\
\hline
\end{tabular}

\section{Conclusions}

The objective of this research was to develop a mathematical model, to calculate the net energy output produced from a Fresnel system as a function of the concentration ratio and different operating condition. The model was applied in the cases of constant and variable solar irradiance and ambient temperature in two cities, namely Stuttgart and Cairo. The model was further developed to account for cooling of the Fresnel system by spraying tap water spraying or chilled water. It is concluded from the results of this study that the critical concentration ratio is a function of the month; where it is very high in the cold months, where the solar irradiance, $E$, is very small and the ambient temperature, $T_{a m b}$, is very low. However, the critical concentration ratio is very low in the hot months due to the high solar irradiance and the high ambient temperature. Cooling using tap water spraying increases the critical concentration ratio. However, a critical concentration ratio doesn't exist in the case of cooling using chilled water because the energy required for cooling is very high compared to the energy generated from the system. Therefore, cooling of the PV panels using chilled water system is not feasible because the energy required for cooling is so high, affecting the net output energy and the feasibility of the system. The critical concentration ratio in general, is high in Stuttgart when compared to that of Cairo. For example, the critical concentration ratio in Stuttgart in July in case of cooling by spraying tap water is 11 , while in Cairo, it is 9 . In December, the critical concentration ratio reaches 41 in Stuttgart, however, it reaches 23 in Cairo. This is due to the low ambient temperature and low solar irradiance in Stuttgart compared to those in Cairo.

\section{References}

[1] Rodrigues, Eduardo MG, Rui Melicio, V. M. F. Mendes, and Joao PS Catalao. "Simulation of a solar cell considering single-diode equivalent circuit model." In International Conference on Renewable Energies and Power Quality, Spain, pp. 13-15. 2011. https://doi.org/10.24084/repqj09.339

[2] Kumar, Prabhat, Vishal Gupta, K. Sudhakar, and Ajay Kumar Singh. "Experimental analysis of comparative temperature and exergy of crystalline (c-Si) and amorphous (a-Si) solar PV module using water cooling method." IOSR Journal of Mechanical and Civil Engineering 13 (2016): 21-26. https://doi.org/10.9790/1684-1305032126

[3] Başak, Özge Demir, and Bekir Sami Sazak. "Effect of components on a solar panel system efficiency." International Journal of Research in Engineering and Technology (IJRET), IACEIT-2014 3, no. 17 (2014): 7-11. https://doi.org/10.15623/ijret.2014.0329002

[4] Xiao, Manxuan, Llewellyn Tang, Xingxing Zhang, Isaac Yu Fat Lun, and Yanping Yuan. "A review on recent development of cooling technologies for concentrated photovoltaics (CPV) systems." Energies 11, no. 12 (2018): 3416.

https://doi.org/10.3390/en11123416

[5] Frank, Elimar, Franz Mauthner, and Stephan Fischer. "Overheating prevention and stagnation handling in solar process heat applications." International Energy Agency-Solar Heating and Cooling Task 49 (2015). https://doi.org/10.18777/ieashc-task49-2015-0001 
[6] Staffell, lain, Daniel Scamman, Anthony Velazquez Abad, Paul Balcombe, Paul E. Dodds, Paul Ekins, Nilay Shah, and Kate R. Ward. "The role of hydrogen and fuel cells in the global energy system." Energy \& Environmental Science 12, no. 2 (2019): 463-491.

https://doi.org/10.1039/C8EE01157E

[7] Myers, Daryl R. "Solar radiation modeling and measurements for renewable energy applications: data and model quality." Energy 30, no. 9 (2005): 1517-1531. https://doi.org/10.1016/i.energy.2004.04.034

[8] Eltawil, Mohamed A., and Zhengming Zhao. "Grid-connected photovoltaic power systems: Technical and potential problems-A review." Renewable and Sustainable Energy Reviews 14, no. 1 (2010): 112-129.

https://doi.org/10.1016/i.rser.2009.07.015

[9] Kvernevik, Eirik Bøhn. "Challenges related to storage and transfer of solar energy with a case study on long distance power transfer." Master's thesis, The University of Bergen (2010).

[10] Abd-Elhady, M. S., M. M. Fouad, and T. Khalil. "Improving the efficiency of photovoltaic (PV) panels by oil coating." Energy Conversion and Management 115 (2016): 1-7. https://doi.org/10.1016/j.enconman.2016.02.040

[11] Abd-Elhady, M. S., Z. Serag, and H. A. Kandil. "An innovative solution to the overheating problem of PV panels." Energy Conversion and Management 157 (2018): 452-459.

https://doi.org/10.1016/j.enconman.2017.12.017

[12] Chaniotakis, Efstratios. "Modelling and analysis of water cooled photovoltaics." Master Thesis, Department of Mechanical Engineering, The University of Strathclyde (2001): 1-84.

[13] Siecker, J., K. Kusakana, and B. P. Numbi. "A review of solar photovoltaic systems cooling technologies." Renewable and Sustainable Energy Reviews 79 (2017): 192-203.

https://doi.org/10.1016/i.rser.2017.05.053

[14] Grubišić-Čabo, Filip, Sandro Nižetić, and Tina Giuseppe Marco. "Photovoltaic panels: A review of the cooling techniques." Transactions of FAMENA 40, no. SI-1 (2016): 63-74.

[15] Chiasson, A. "Waste heat rejection methods in geothermal power generation." In Geothermal Power Generation, pp. 423-442. Woodhead Publishing, 2016. https://doi.org/10.1016/B978-0-08-100337-4.00015-2

[16] Smith, Craig B., and Kelly E. Parmenter. "Electrical energy management in buildings." In Energy Management and Conservation Handbook, pp. 95-134. CRC Press, 2016.

https://doi.org/10.1201/9781315374178-6

[17] Rosli, Mohd Afzanizam Mohd, and Hasif Jamil. "Analysis of Photovoltaic Thermal Using F-Chart Method for Domestic Hot Water." CFD Letters 57, no. 2 (2019):50-65.

[18] Wu, Shenyi, and Chenguang Xiong. "Passive cooling technology for photovoltaic panels for domestic houses." International Journal of Low-Carbon Technologies 9, no. 2 (2014): 118-126. https://doi.org/10.1093/ijlct/ctu013

[19] Abdelrahman, M., Abdellatif Eliwa, and O. E. Abdellatif. "Experimental investigation of different cooling methods for photovoltaic module." In Joint Propulsion Conferences, pp. 14-17. 2013. https://doi.org/10.2514/6.2013-4096

[20] Edaris, Zahratul Laily, Mohd Sazli Saad, Mohammad Faridun Naim Tajuddin, and Sofian Yusoff. "Photovoltaic/Thermal Water Cooling: A Review of Experimental Design with Electrical Efficiency." In Proceedings of the Second International Conference on the Future of ASEAN (ICOFA) 2017-Volume 2, pp. 245-254. Springer, Singapore, 2018.

https://doi.org/10.1007/978-981-10-8471-3 24

[21] Akbarzadeh, A., and T. Wadowski. "Heat pipe-based cooling systems for photovoltaic cells under concentrated solar radiation." Applied Thermal Engineering 16, no. 1 (1996): 81-87. https://doi.org/10.1016/1359-4311(95)00012-3

[22] Kalogirou, Soteris A. "Use of TRNSYS for modelling and simulation of a hybrid pv-thermal solar system for Cyprus." Renewable Energy 23, no. 2 (2001): 247-260. https://doi.org/10.1016/S0960-1481(00)00176-2

[23] Ghazali, A., E. Salleh, C. H. Lim, K. Sopian, and S. Mat. "Economic Evaluation of Vertical Photovoltaic System on Highrise Building in Malaysia." Journal of Advanced Research in Business and Management Studies 3, no. 1 (2016): 123138.

[24] Abdolzadeh, M., and M. Ameri. "Improving the effectiveness of a photovoltaic water pumping system by spraying water over the front of photovoltaic cells." Renewable Energy 34, no. 1 (2009): 91-96. https://doi.org/10.1016/i.renene.2008.03.024 
[25] Musthafa, M. Mohamed. "Enhancing photoelectric conversion efficiency of solar panel by water cooling." Journal of Fundamentals of Renewable Energy and Applications 5, no. 4 (2015): 1-5.

[26] Abdulgafar, Sayran A., Omar S. Omar, and Kamil M. Yousif. "Improving the efficiency of polycrystalline solar panel via water immersion method." International Journal of Innovative Research in Science, Engineering and Technology 3, no. 1 (2014): 96-101.

[27] Sakhaei, Seyed Ali, and Mahbod Safari. "Study and comparison of inlet air cooling technique of gas turbines and their effects on increase of the efficiency and outlet power." International Journal of Materials, Mechanics and Manufacturing 2, no. 4 (2014): 329-334.

https://doi.org/10.7763/IJMMM.2014.V2.151

[28] Nižetić, Sandro, Duje Čoko, A. Yadav, and Filip Grubišić-Čabo. "Water spray cooling technique applied on a photovoltaic panel: The performance response." Energy Conversion and Management 108 (2016): 287-296. https://doi.org/10.1016/i.enconman.2015.10.079

[29] Dupré, Olivier, Rodolphe Vaillon, and Martin A. Green. "Thermal behavior of photovoltaic devices." Physics and Engineering 10 (2017): 978-3. https://doi.org/10.1007/978-3-319-49457-9

[30] Moharram, Khaled A., M. S. Abd-Elhady, H. A. Kandil, and H. El-Sherif. "Enhancing the performance of photovoltaic panels by water cooling." Ain Shams Engineering Journal 4, no. 4 (2013): 869-877.

https://doi.org/10.1016/j.asej.2013.03.005

[31] García, MC Alonso, and J. L. Balenzategui. "Estimation of photovoltaic module yearly temperature and performance based on nominal operation cell temperature calculations." Renewable Energy 29, no. 12 (2004): 1997-2010. https://doi.org/10.1016/i.renene.2004.03.010

[32] Skoplaki, Elisa, and John A. Palyvos. "On the temperature dependence of photovoltaic module electrical performance: A review of efficiency/power correlations." Solar Energy 83, no. 5 (2009): 614-624. https://doi.org/10.1016/i.solener.2008.10.008

[33] Othieno, Herick, and Joseph Awange. Energy resources in Africa. Springer International Publishing: Basel, Switzerland, 2016. https://doi.org/10.1007/978-3-319-25187-5 